\title{
By-catch mortality of beaked Sea Snake Hydrophis schistosus (Daudin, 1803) by entanglement in shore-seine operation in Goa-India
}

\author{
Gangadhar TAMBre, ${ }^{1}$ SambHaji MOTE, ${ }^{2}$ Kalyan De, ${ }^{3}$ DeEPa YOGi, ${ }^{4}$ \\ MAHESH JADHAV, ${ }^{5}$ BABAN INGOLE, ${ }^{6}$ TAPAS CHATTERJEE, ${ }^{7}$ MANDAR NANAJKAR ${ }^{8}$ \\ ${ }^{1}$ CSIR-National Institute of Oceanography, Dona Paula, Goa- 403004, India, ORCID: 0000-0002-8740-3173 \\ 2 CSIR-National Institute of Oceanography, Dona Paula, Goa- 403004, India, ORCID: 0000-0002-2238-4856 \\ ${ }^{3}$ CSIR-National Institute of Oceanography, Dona Paula, Goa- 403004, India, ORCID: 0000-0002-9722-2309 \\ ${ }^{4}$ CSIR-National Institute of Oceanography, Dona Paula, Goa- 403004, India, ORCID: 0000-0002-3268-7906 \\ ${ }^{5}$ CSIR-National Institute of Oceanography, Dona Paula, Goa- 403004, India, ORCID: 0000-0003-4867-3661 \\ ${ }^{6}$ CSIR-National Institute of Oceanography, Dona Paula, Goa- 403004, India, ORCID: 0000-0001-6096-6980 \\ ${ }^{7}$ Near Harimandir Road, Dhanbad 826001, Jharkhand, India, ORCID: 0000-0001-5532-2726 \\ ${ }^{8}$ CSIR-National Institute of Oceanography, Dona Paula, Goa- 403004, India, ORCID: 0000-0002-6608-7669 \\ Corresponding author e-mail: mandar@nio.org
}

Keywords Sea snake, Hydrophis schistosus, Arius jella, by-catch, Goa; India

Abstract Hydrophis schistosus (Daudin, 1803) commonly known as beaked sea snake occurs in shallow marine and estuarine habitats of India. The population of H. schistosus has been frequently noted in the shore-seine net as By-catch. Only a few studies are available about By-catch of sea snakes in Indian coasts. Being a top predator, their mortality and ecological consequences are largely unknown. The present study was conducted along the Caranzalem-Miramar coast of Caranzalem bay, Goa during monsoon (August-September, 2017 and 2018) to focus on the by-catch mortality of $H$. schistosus and their feeding preferences. Observations indicated that the fishing activities, particularly during every shore-seine operation, results in a significant by-catch of sea snakes where approximately 20-60 individuals get entangled in the fishing net. The study indicated a large number $(90 \%)$ of juveniles being caught in the shore-seine. Gut content analysis of $H$. schistosus revealed that $80 \%$ of snakes preferred catfish Arius jella as the desired prey species. Sea snakes being top predator play a vital role in checking the local catfish population. Hence, in concern to save H. schistosus population and sea snakes, in general, the fishing methods, as well as awareness towards conservation of sea snakes among fishermen, should be raised.

\section{Śmiertelność węża morskiego Hydrophis schistosus (Daudin, 1803) w sieciach typu niewód w Goa - Indie \\ Słowa kluczowe wąż morski, Hydrophis schistosus, Arius jella, sum morski, przyłów, Goa, Indie}

Streszczenie Wąż Hydrophis schistosus (Daudin, 1803) występuje powszechnie w płytkich wodach morskich i estuariach na wybrzeżu Indii, gdzie często jest łapany jako przyłów w sieciach typu niewód. 
Do dzisiaj niewiele wiadomo na temat wielkości przyłowu tego gatunku na wybrzeżu Indii. Ponieważ wąż ten jest drapieżnikiem znajdującym się wysoko w piramidzie troficznej ekosystemu wód przybrzeżnych Indii, jego dodatkowa śmiertelność może mieć znaczący wpływ na funkcjonowanie całego ekosystemu. W artykule zawierto dane dotyczące wielkości przyłowu I preferencji pokarmowych $H$. schistosus z wybrzeża Caranzalem-Miramar zatoki Caranzalem (Goa) w czasie monsunu (sierpień-wrzesień, 2017 i 2018 r.). Obserwacje wskazują, że aktywność rybacka, a szczególnie używanie sieci typu niewód, powodują znaczną śmiertelność węży (20-60 osobników zaplątanych w jednej sieci). Młode osobniki stanowią 90\% przyłowu. Analiza żołądków H. schistosus wykazała, że $80 \%$ węży preferowała suma morskiego Arius jella jako zdobycz, co powodowało częste zaplątywanie się węży w sieci używane do połowu suma morskiego. Konieczne jest rozważenie alternatywnych metod połowowych, aby uniknąć przyłowu węży.

\section{Introduction}

Sea snakes are an integral part of coastal ecosystem in the tropical Indo-Pacific region and they comprise about $86 \%$ of living marine reptile species (Rasmussen, 2011). They inhabit the soft bottom shallow coastal seas to lagoons, estuaries and mangrove areas (Limpus, 1975; Sharma, 2007). Sea snakes are active migrants in the sea but they are less efficient on land and die usually if stranded on the beach for a longer duration (Whitaker et al., 2004; Duarte, 2009).

Sea snakes are protected in Australia under the Environment Protection Biodiversity and Conservation Act 1999, but they are listed as Least Concerned (LC) in the IUCN Red list of threatened species (IUCN, 2018). The beaked sea snake Hydrophis schistosus (=Enhydrina schistosa) (Daudin, 1803), is a well-distributed Indo-Pacific species and reported as most common species from the Indian coast (Lobo et al., 2004). This species is known for its highly potent neurotoxin as the venome more toxic than those of land snakes; nevertheless, they are found to be rarely aggressive (Chippaux, 1998; Senanayake et al., 2005) despite it, most of the fatalities due to sea snake's bite are associated with H. schistosus around the globe (Reid, 1975). The occurrence of this species has been well reported from the entire Indian coast (Lobo et al., 2004; Karthikeyan, Balasubramanian, 2007; Zacharia, 2008; Walmiki et al., 2012; Muthukumaran et al., 2015; Hatkar, Ramesh, 2016). Studies indicate that estuaries comprise a suitable habitat for this species during pre-monsoon and monsoon season to provide ample food or bearing young (Shantov, 1971; Wassenberg et al., 1994). H. schistosus is a piscivorous species preferentially feeding on Catfishes and Pufferfish (Voris et al., 1978; Garrett et al., 1982; Jeyabaskaran et al., 2015) but also forage on species of Clupeidae and Engraulidae and fish eggs (Lobo et al., 2005; Emilie et al., 2010).

In India, this species is also impacted by coastal pollution (Mote et al., 2015) and commonly encountered as a trawl by-catch and other fishing operation (Rao et al., 2017). The commercial fishing operation appears to be the foremost threat to this sea snake species due to high volume by-catch (Padate et al., 2009). Due to sporadic reporting of this species mainly as a product of by-catch associated mortality, a significant knowledge gap exists about the population ecology (Hatkar, Ramesh, 2016) and feeding preferences from Indian waters. The aim of the present study was to know the sea snakes by-catch fate and feeding preferences of these top predators. The present observation highlights the ecological importance of Hydrophis schistosus wherein we hypothesize that as mega-benthic predators they profoundly influence the local estuarine benthic food chain. 


\section{Materials and Methods}

\section{Study area}

The present study was carried on the central west coast of India at Caranzalem-Miramar coast

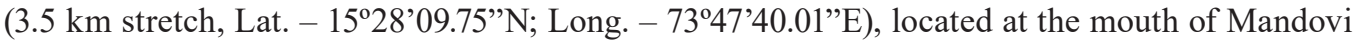
estuary (Figure 1). This place is known for fishing by artisanal fishing by local community and also a popular tourist beach in Goa.

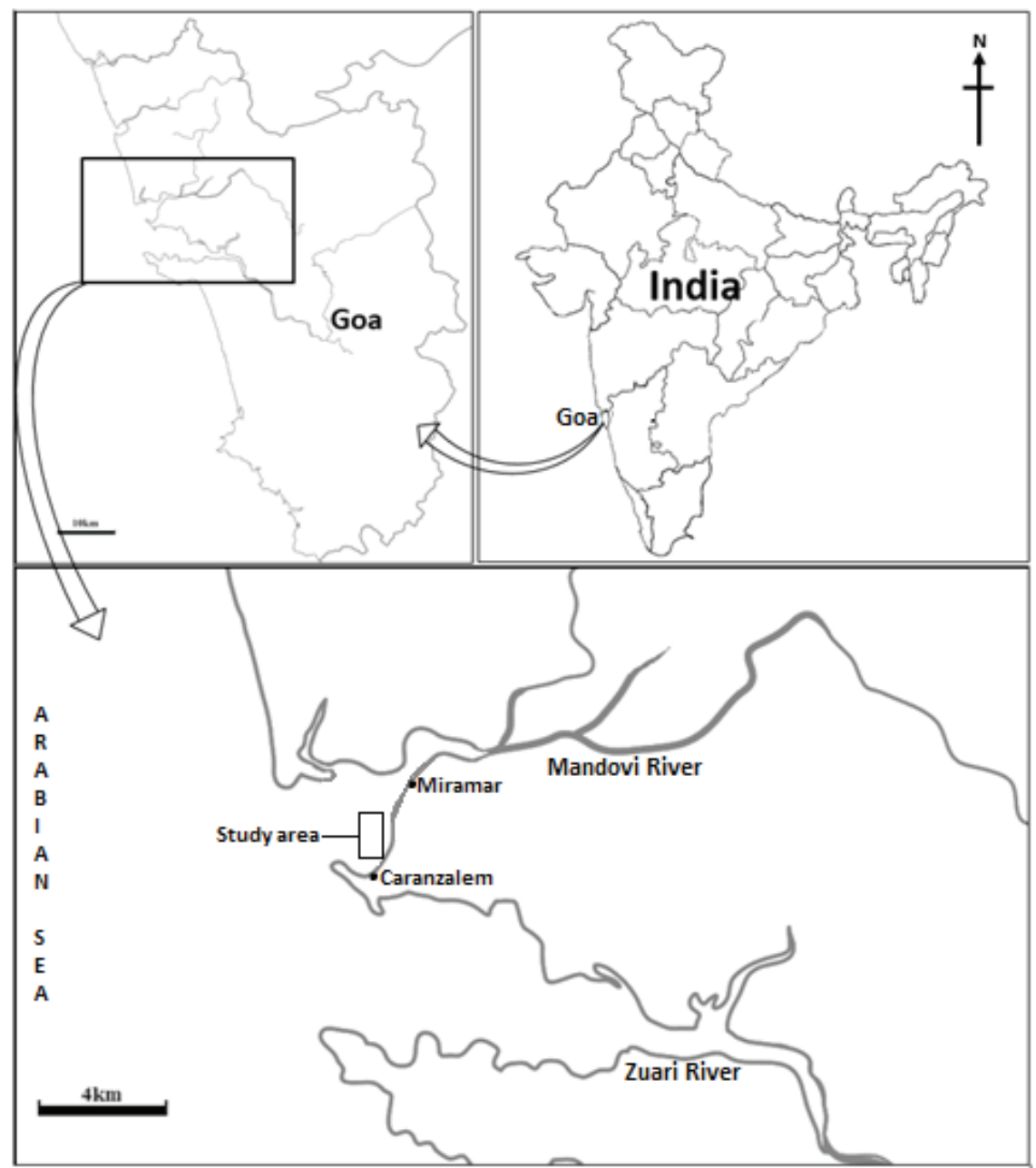

Figure 1. Location of the study area 


\section{Collection of sample}

Sampling was carried out twice in a week during August-September 2017 and 2018 after the annual fishing ban period (June-July, a total 61 days during the Southwest monsoon). Counts were carried out of all the sea snakes entangled in the shore-seine net and landing on the beach, followed by a count of dead and live sea snakes. Immediately, after the sorting of landed fishes live snakes were released back into the sea while the dead snakes were brought to the laboratory for further analysis. Morphological identification confirmed that the sea snake species is Hydrophis schistosus (Rasmussen, 2001). Fishing gears operated in study area were noted, which revealed that traditional fishing activities such as shore-seine net (locally known as 'Rampani/Yandi'), operated at a depth of 4-5 m, covering an area of $1.5 \mathrm{~km}^{2}$ at the mouth of the Mandovi estuary (Figure 2a). The mesh size varies from 10-20 mm and seine nets use sinkers at the bottom and float at the surface, and manually dragged. This traditional fishing method results in the considerable amount of by-catch along with the targeted fish species (Figure 2b). Significant by-catch of sea snakes H. schistosus during this fishing operation (Figure 2c) was noted. In the laboratory, measurements were conducted for length-weight of each dead snake specimen $(n=40)$ followed by gut content analysis (Figure 2d, e).

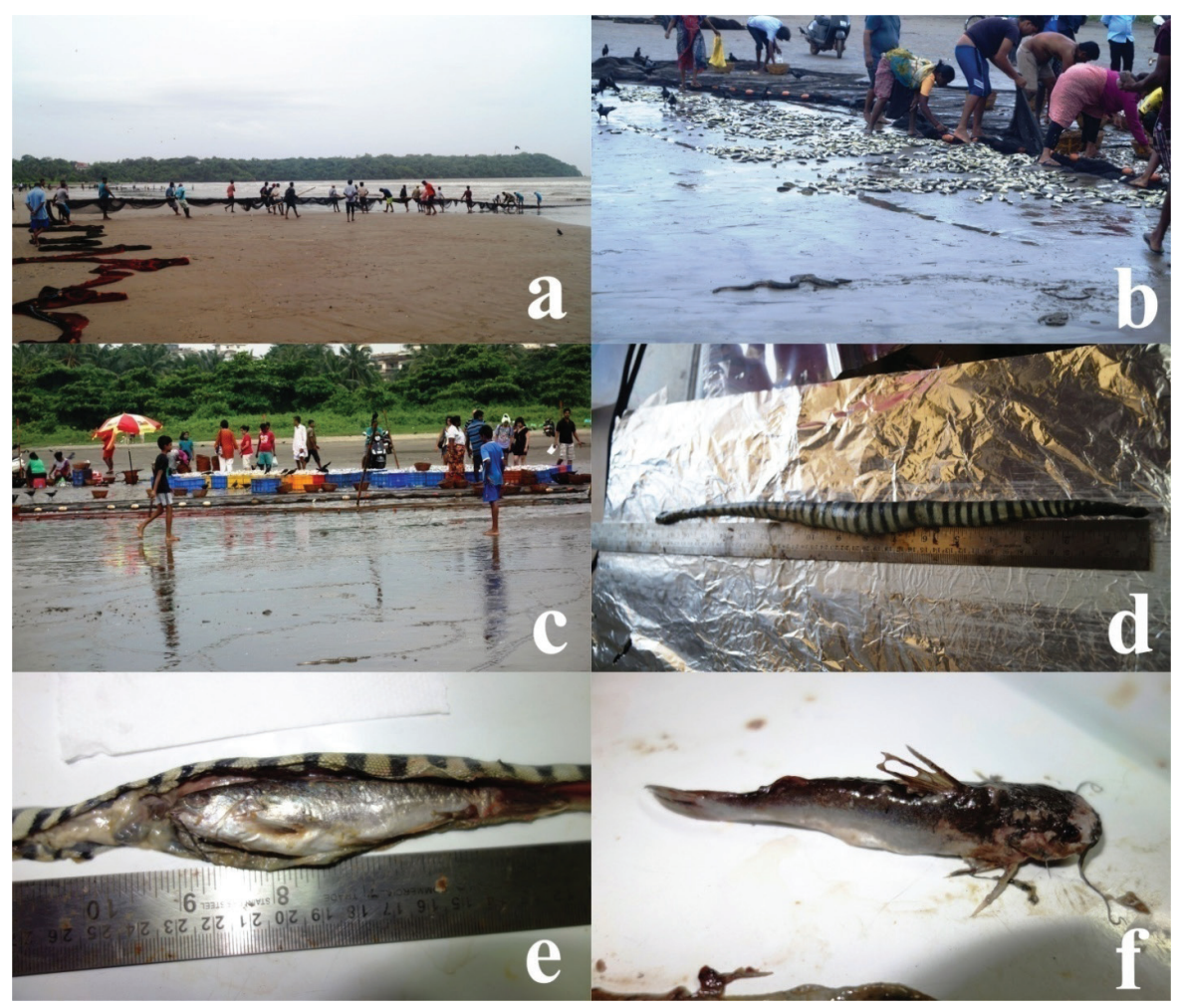

Figure 2. In-situ and laboratory observations during the study (a) Seine net operation activity, (b) Discard of by-catch during sorting, (c) Sorted catch after hauling and By-catch removal (note the trails in the fore ground made by stranded snakes), (d) Sea snake species Hydrophis schistosus, (e) Dissected H. schistosusshowing gut content, (f) Specimen from the gut (indigested Arius jella) 
By-catch mortality of beaked Sea Snake Hydrophis schistosus (Daudin, 1803)...

The species gut content confirmed as Arius jella using standard literature (Fischer and Bianchi, 1984).

\section{Results}

A total of 1,448 individuals (ind.) of $H$. schistosus were landed as by-catch during the study period. In 2017, 920 ind. were counted in by-catch (695 live and 225 dead), among those 89 were adults $(9.67 \%$ of total catch; Mean $5.6 \pm 1.59$ SD) and 831 juveniles $(90.3 \%$ of total catch; Mean $51.9 \pm 11.82 \mathrm{SD}$ ). While in 2018, total 528 ind. of $H$. schistosus were recorded, among them 56 were adults $(10.6 \%$ of total catch; Mean $3.5 \pm 1.90 \mathrm{SD})$ and 472 juveniles $(89.4 \%$ of total catch Mean $29.5 \pm 12.69 \mathrm{SD}$ ), among those 407 were alive and 121 were dead (Table 1). Other by-catch species along with sea snake H. schistosus were Bamboo sharks, Stingrays, Guitarfishes, Puffers, Catfish and other pelagic juveniles of fishes.

Table 1 . Account of $H$. schistosus by-catch during the study period

\begin{tabular}{|c|l|c|c|c|c|c|}
\hline \multicolumn{2}{|c|}{ Year } & $\begin{array}{c}\text { Total no. } \\
\text { of H. schistosus }\end{array}$ & Adults & Juveniles & Live & Dead \\
\hline \multirow{3}{*}{2017} & total & 920 & 89 & 831 & 695 & 225 \\
\cline { 2 - 7 } & mean & 57.5 & 5.6 & 51.9 & 43.4 & 14.1 \\
\cline { 2 - 7 } & SD & 12.61 & 1.59 & 11.82 & 11.74 & 4.55 \\
\cline { 2 - 7 } & percentage & - & 9.7 & 90.3 & 75.5 & 24.5 \\
\hline \multirow{3}{*}{2018} & total & 528 & 56 & 472 & 407 & 121 \\
\cline { 2 - 7 } & mean & 33 & 3.5 & 29.5 & 25.4 & 7.6 \\
\cline { 2 - 7 } & SD & 14.13 & 1.90 & 12.69 & 10.09 & 4.47 \\
\cline { 2 - 7 } & percentage & - & 10.6 & 89.4 & 77.1 & 22.9 \\
\hline
\end{tabular}

The length-weight ratio of $H$. schistosus indicated the presence of juveniles and sub-adults with an average length of $43 \mathrm{~cm}$ and weight $35 \mathrm{~g}$ (Figure 3). Among the dead specimen collected for laboratory analysis, only one adult was noted with length $97 \mathrm{~cm}$ and weighing $359 \mathrm{~g}$. Generally, H. schistosus attain maturity at a length of 66-73 cm (Voris, Jayne, 1979; Rasmussen, 2001; Jeyabaskaran et al., 2015). The gut content analysis of $H$. schistosus revealed presence of catfish A. Jella in $80 \%$ of snake specimens (Figure $2 \mathrm{f}$ ) and the remaining $20 \%$ guts were empty or with the semi-digested or completely digested material (identification of prey items was not possible). The length of $A$. Jella in snake gut varied between $4.32-11.68 \mathrm{~cm}$ (Mean $5.94 \pm 1.65 \mathrm{SD}$ ) and weighed between 0.11-11.79 g (Mean $1.42 \pm 1.89$ SD). 


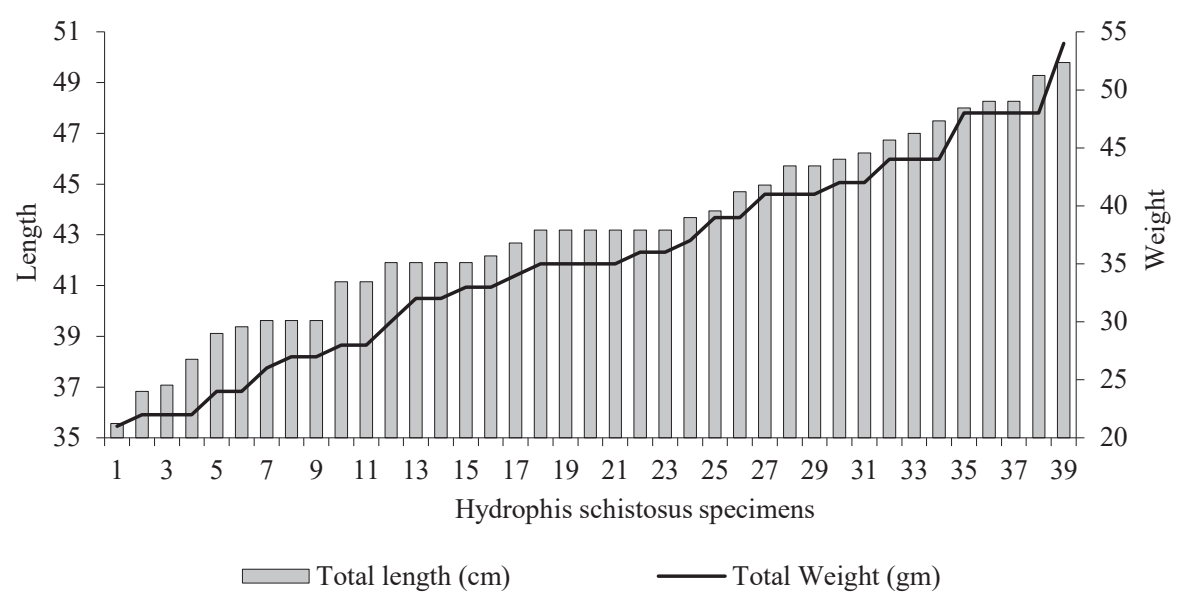

Figure 3. Length-weight ratio of $H$. schistosus sampled at the study location

\section{Discussion}

The mortality of sea snake $H$. schistosus was found to be high in this part of the Arabian Sea. Rao et al. (2017) recorded a total 379 species of sea snakes as by-catch at Vengurla, Devgarh and Sindhudurg districts of Maharashtra within $100 \mathrm{~km}$ of present study area. Whereas, Padate et al. (2009) encountered 43 individuals of H. schistosus in 70 trawl operations. While on the east coast of India, Muthukumaran et al. (2015) reported the occurrence of 234 entangled sea snakes in trawling nets and seine nets. Several studies revealed that most of the specimens were juveniles and sub-adults (Dell et al., 2009). Use of traditional shore-seine nets is widespread in the Indian coast and known for its by-catch discards where in sea snakes are usually discarded on the shore (Raj et al., 2017). Out of all the sea snakes, Wassenberg et al. (1994) revealed that about $88 \%$ of $H$. schistosus being caught as by-catch in the coastal region at the Gulf of Carpentaria, Australia.

During this study, approximately 20-60 live H. schistosus entangled were found after hauling of the shore-seine net on the beach (Table 1). Therefore, considering their high abundance in the by-catch indicates that estuarine mouth benthic environment serves as an important habitat for the juveniles by providing ample food. By-catch related mortality of juvenile of marine species arises across the world oceans, as well as in Indian seas is a serious concern (Bijukumar, Deepthi, 2006; Lobo, 2012). A large quantity of by-catch and discard due to trawling and unregulated use of small meshed net causes loss of marine life including endangered species like sea turtle, sea horses and elasmobranchs (Shankar et al., 2004; Salin et al., 2005; Tiralongo et al., 2018).

The present study site at the Mandovi estuary is known to be highly productive area (Kumari et al., 2002; Ansari et al., 2003) and attracts a rich diversity of fishes as it also serves as a nursery ground for most of the species. The high abundance of sea snakes during post-monsoon as compared to pre-monsoon season has been reported in estuarine and inshore waters of Goa and the abundance of small-sized fish attracts more sea snakes into this habitat (Padate et. al., 2009). Several mega-benthic predators including sea-snakes, mostly juveniles and sub-adults forage the 
area and take refuge in the bay (Brown et al., 2013). Reportedly juveniles of H. schistosus may remain in estuarine and riverine habitats for protection and migrate into open water when nearing maturity (Voris, Jayne, 1979; Voris, 1985). The increased number of sea snake H. schistosus juveniles in the present study suggest that by-catch mortality is alarming in this area, compared to adjacent regions of Maharashtra, Pondicherry, Kerala and Tamilnadu states of India (Karthikeyan, 2007; Jeybasskaran et al., 2015; Muthukumaran, 2015; Rao et al., 2017). Sea snakes are also known for their philopatry and site fidelity (Shetty, Shine, 2002); therefore, continuous by-catch allied mortality of this species in the study area could wipe out the local population and could impose broad scale effect on the ecosystem as well as the artisanal fishery in the region.

The gut content analysis revealed the catfish $A$. jella as the only prey species of $H$. schistosus indicating species specificity. Such a high preference for Ariid catfishes was also noted by Voris et al. (1978) in a feeding experiment as H. schistosus prefers benthic organisms as their prey items (McCosker, 1975; Voris, Jayne, 1979). Moreover, the ray finned catfish $A$. jella is a known benthic predator (Ritukumari, Rajukumar, 2007) and regionally has low commercial value as compared to the other economically important fishes. This implies that as a top predator, this sea snake $H$. schistosus controls the population of $A$. jella in the coastal subtidal benthic habitats. As a megabenthic important predator, if $H$. schistosus a natural predator of $A$. jella is removed from the habitat, $A$. jella will dominate this habitat as it is voracious feeder and an omnivore. This dominance of $A$. jella will indirectly out compete other economically important species of Carangidae, Stromateidae, Sciaenidae, Sillaganidae and Cynoglossidae families which are wellnoted from the study area (Noted from shore-siene operation). Apparently, due to reduced predatory pressure, the catfish dominance could impact the population dynamics of other benthic species in the bay and result in population reduction of other commercially important species.

Although the exact population of the H. schistosus in the bay region is difficult to decipher, but based on the by-catch mortality it can be said that considerable loss of population may result in ecosystem-level repercussions. Because of habitat destruction and capture a large number of nontarget species and juveniles, small meshed seine nets are considered to be detrimental practice (Divakarannair, 2007). However, by-catch reduction is achievable through mesh size regulation with fixed and regulatory bans (Boopendranath et al., 2007); hence, strict implementation of mesh size regulation should be followed. Additionally, development and use of excluder devices and speedy release of the entangled snakes could help to avoid human fatalities and save the sea snake population (Steve, 2007). In addition, worldwide decline of sea snake population is alarming and the high mortality rate of these diminishing populations could threaten the ecosystem (Gibbons, 2000). A long-term monitoring program and the implementation of proper conservation strategies are required to protect this species.

\section{Acknowledgment}

Authors would like to thanks the Director, CSIR National Institute of Oceanography, Dona Paula, Goa for providing laboratory facilities. 


\section{References}

Ansari, Z.A., Sreepada, R.A., Dalal, S.G., Ingole, B.S., Chatterjee, A. (2003). Environmental influences on the trawl catches in a bay-estuarine system of Goa, West coast of India. Estuarine, coastal and shelf science, 56, 503-515.

Bijukumar, A., Deepthi, G.R. (2006). Trawling and By-catch: Implications on marine ecosystem. Current Science, 90 (7), 922-931.

Boopendranath, M. (2007). Possibilities of By-catch reduction from trawlers in India. Indian Fisheries-A progressive outlook. Kochi: ICAR, Central Marine Fisheries Research Institute.

Brown, J.A., Burton, E.J. Beukelaer, S.D. (2013). The Natural Resources of Monterey Bay National Marine Sanctuary: A focus on Federal waters. Marine Sanctuaries Conservation Series ONMS-13-05. U.S. Department of Commerce, National Oceanic and Atmospheric Administration, office of National Marine Sanctuaries, Silver Spring, MD.

Chippaux, J.P. (1998). Snake-bites: appraisal of the global situation. Bulletin of World Health Organisation, $76,515-524$

Dell, Q., Griffiths, S.P., Heales, D.S., Tonks, M.L. (2009). By-catch in a tropical schooling - penaeid fishery and comparisons with a related, specialized trawl regime. Fisheries Management and Ecology, 16, 191-201.

Divakarannair, N. (2007). Livelihood Assets and Survival Strategies in Coastal Communities in Kerala, India. India: Jawaharlal Nehru University.

Duarte, C.M. (2009). Marine ecology. EOLSS Publishers, UNESCO, ISBN-978-1-84826-014-6.

Emilie, A., Sharma, S.K., Bawaskar, H.S., Kuch, U., Chappuis, F. (2010). Snake Bite in South Asia: A Review. PLOS, Neglected Tropical Diseases, 4 (1), e603.

Fischer, W., Bianchi, G. (1984). FAO species identification sheets for fisheries purposes, Western Indian Ocean. Marine resources service. Rome: FAO fisheries department.

Garrett, S.G.,Voris, H.K. (1982). Marine snake Diets: Prey composition, diversity and overlap. Copeia, 3, 661-666.

Gibbons, J.W., Scott, D.E., Ryan, T.R., Buhlmann, K.A., Tuberville, T.D., Metts, B.S., Greene, J.L., Mills, T., Leiden, Y., Poppy, S., Winne, C.T. (2000).The global decline of reptiles. De javu Amphibians, Bioscience, 50 (8), 653-666.

Hatkar, P., Ramesh, C. (2016). A comprehensive report on the Hook-nosed Sea Snake Enhydrina schistosa (Daudin, 1803). Reptile Rap, 18, 19-22.

http://hdl.handle.net/1828/260.

Jeyabaskaran, R., Abhilash, K.S., Gishnu, M., Vishnu, P.G., Mohamed, A., Aswathy, K.S., Khambedkar, L.R., Prema, D., Kripa, V. (2015). Some observations on the beaked sea snake Enhydrina schistosa (Daudin, 1803) in the mudbank area, off Alapuzha, Kerala, southwest coast of India. Journal of Marine Biological Association, India, 52 (2), 109-112.

Karthikeyan, R., Balasubramanian, T. (2007). Species diversity of sea snake (Hydrophiidae) distributed in the coramantal coast (East coast of India). International Journal of Zoological Research, 3, 107-131.

Kumari, L.K., Bhattathiri, P.M.A., Matondkar, S.G.P., John, J. (2002). Primary productivity in MandoviZuary estuaries in Goa. Journal of Marine Biological Association, India, 44 (1-2), 1-13.

Limpus, C.J. (1975). Coastal sea snakes of subtropical Queensland waters (23 to $28^{\circ}$ south latitude). In: W.A. Dunson (ed.), The Biology of Sea Snakes (pp. 173-182). Maryland: University Park Press, Baltimore.

Lobo, A., Pandav, B., Karthikeyan, V. (2004). Weight-length relationships in two species of marine snakes along the coast of Goa. Western India. Hamadryad, 29, 89-93. 
By-catch mortality of beaked Sea Snake Hydrophis schistosus (Daudin, 1803)...

Lobo, A.S. (2012). Managing Fisheries in an Ocean of By-catch. Position paper for CBD-COP 11. Anand: Dakshin Foundation, Bengaluru, and Foundation for Ecological Security.

Lobo, A.S., Karthikeyan, V., Pandav, B.(2005). Trophic Ecology of Lapemiscurtus (Hydrophiinae) along the Western Coast of India. Copeia, 3, 637-641. https://doi.org/10.1643/CH-04-076R1.

McCosker, J.E. (1975). Feeding behavior of Indo-Australian hydrophiidae. The biology of sea snakes. Baltimore MD: University Park Press.

Mote, S., Kumar, R., Naik, B.G., Ingole, B.S. (2015). Polycyclic Aromatic Hydrocarbons (PAHs) and nAlkanes in Beaked Sea Snake Enhydrina schistosa (Daudin, 1803) from the Mandovi Estuary, Goa. Bulletin of Environmental Contamination and Toxicology, 94, 171-177.

Muthukumaran, M., Rao, V.B., Alexander, R. (2015). Threats of passive fishing activities on sea snake Enhydrina schistosa (Daudin 1803) of Puducherry coast, India. International Journal of Pure and Applied Zoology, 3, 53-58.

Padate, V.P., Baragi, L.V., Rivonkar, C.U. (2009). Analysis of few biological aspects of sea snakes caught incidentally by commercial trawlers off Goa, West coast of India. Journal of Threatened Taxa, 12 (1), 606-612.

Raj, K.D., Sundar, M., Edward, J.K.P. (2017). Impact of traditional shore-seine operation along the Tuticorin coast, Gulf of Mannar, Southeast India. Current Science, 112 (1), 40-45 Doi: 10.18520/cs/v112/ i01/40-45.

Rao, C., Gupta, T., D’souza, S., Manoharkrishnan. (2017). Effect of fishing practices on species assemblages of sea snakes off the Sindhudurg coast of Maharashtra, India. Dakshin Foundation, Bangalore, India.

Rasmussen, A., Sanders, K., Lobo, A., Courtney, T. (2018). Hydrophis schistosus (amended version of 2010 assessment). The IUCN Red List of Threatened Species 2018, e.T176719A136258180.

Rasmussen, A.R, Murphy, J.C, Ompi, M., Gibbons, J.W., Uetz, P. (2011). Marine reptiles. PLoS ONE, 6 (11), e27373.

Rasmussen, A.R. (2001). Sea snakes, In: Carpenter KE, Niem VH (Eds) FAO species identification guide for fishery purposes. The living marine resources of the Western Central Pacific. Food Agri Org, 619 (6), 3987-4008.

Reid, H.A. (1975). Epidemiology of sea snake bites. Journal of Tropical Medicine and Hygiene, 78 (5), $106-113$.

Salin, K.R., Yohannan, T.M., Nair, C.M. (2005). Fisheries and trade of Seahorses, Hippocampus spp., in Southern India. Fisheries management and ecology, 12, 269-273.

Senanayake, M.P., Ariaratnam, C.A., Abeywickrema, A., Belligaswatte, A. (2005). Two Srilankan Cases of Sea snake bites, without envenoming. Toxicon, 45, 861-863.

Shanker, K., Pandav, B.,Choudhary, B.C. (2004). An assessment of the olive ridley turtle (Lepidochely solivacea) nesting population in Orrisa, India. Biological Conservation, 115, 149-160.

Sharma, R.C.(2007). Fauna of India and the adjacent countries. Reptilia Vol. 3. Kolkata: Zoological Survey of India.

Shetty, S., Shine, R.(2002). Philopatry and Homing behavior of sea snakes (Laticauda colubrina) from two adjacent Islands in Fiji. Conservation Biology, 16 (5), 1422-1426.

Shuntov, V.P. (1971). Sea snakes of the North Australian shelf (In Russian). Ekologiya, 2, 65-72.

Steve, E.(2007). A guide to By-catch reduction in tropical shrimp-trawl fisheries. Rome: Food and Agricultural Organization of the United Nations.

Tiralongo, F., Messina, G., Lombardo, B. M.(2018). Discards of elasmobranchs in a trammel net fishery targeting cuttlefish, Sepia officinalis Linnaeus, 1758, along the coast of Sicily (Central Mediterranean Sea). Regional Studies in Marine Science, 20, 60-63. 
Voris, H.K. (1985). Population size estimates for a marine snake (Enhydrina schistosa) in Malaysia. Copeia, 4, 955-961.

Voris, H.K., Jayne, B. C.(1979). Growth, reproduction and population structure of a marine snake, Enhydrina schistosa (Hydrophiidae). Copeia, 2, 307-318.

Voris, H.K., Voris, H.H., Liat, L.B. (1978). The food and feeding behavior of Enhydrina schistosa. Copeia, $1,134-146$.

Walmiki, N., Karangutkar, S., Yengal, B., Kayande, M., Wagh, V., Pillai, R., Dalvi, S. (2012). Herpeto fauna of Bassein Fort and surrounding region, Thane, Maharashtra, India. Trends in life sciences, 1 (3), 1-7.

Wassenberg, T.J., Salini, J.P., Heatwole, H., Kerr, J.D. (1994). Incidental capture of sea snakes (Hydrophiidae) by Prawn trawlers in Gulf of Carpentaria, Australia. Australian Journal of Marine and Freshwater resources, 45, 429-443.

Whitaker, R., Captain, A., Ahmed, F. (2004). Snakes of India. Chennai: Draco Books.

Zacharia, P.U. (2008). Species assemblage in the coral reef ecosystem of Netrani Island off Karnataka along the southwest coast of India. Journal of Marine Biological Association, India, 50, 87-97.

Cite as: Tambre, G., Mote, S., De, K., Yogi, D., Jadhav, M., Ingole, B., Chatterjee, T., Nanajkar, M. (2020). By-catch mortality of beaked Sea Snake Hydrophis schistosus (Daudin, 1803) by entanglement in shoreseine operation in Goa-India. Acta Biologica, 27, 67-76. DOI: 10.18276/ab.2020.27-07. 